\title{
Feeding Strategy of Ruminants and Its Potential Effect on Methane Emission Reduction
}

\author{
B. Suwignyo ${ }^{1}$, B. Suhartanto ${ }^{1}$, N. Umami ${ }^{1}$, N. Suseno ${ }^{1} \&$ Z. Bachruddin ${ }^{1}$ \\ ${ }^{1}$ Faculty of Animal Science, Universitas Gadjah Mada, Yogyakarta, Indonesia \\ Correspondence: B. Suwignyo, Faculty of Animal Science, Universitas Gadjah Mada, Yogyakarta, Indonesia. Tel: \\ 62-(0)-274-513-363. E-mail: bsuwignyo@ugm.ac.id
}

Received: May 30, 2016

doi:10.5539/jas.v8n9p199
Accepted: July 26, $2016 \quad$ Online Published: August 15, 2016

URL: http://dx.doi.org/10.5539/jas.v8n9p199

\begin{abstract}
A study was conducted to determine the potential effect of Leucaena leucocephalain the diet with 3 levels $0 \%$, $6 \%, 12 \%$ of ration on the population of rumen methanogenic bacteria of cattle and buffalo. Three each ruminally-fistulated (body weight $342 \pm 66.93 \mathrm{~kg}$ ) were used in this experiment. The amount of feed offered was $2.5 \%$ of live weight on DM basis. Rumen fluid was collected from each animal before feeding, after 17 days on feed. The rumen fluid was strained it through cheesecloth and stored in freezer prior to analysis. The samples were subjected to DNA extraction and amplification. Three universal primers were used to detect methanogenic bacteria, which had more than one band, ranging from $500 \mathrm{bp}$ and $1.4 \mathrm{kbp}$. The results indicated that the level of Leucaena leucocephala in the diets reduced the population of methanogenic rumen bacteria of the cattle and enhanced the Fibrobacter succinogenes. Thus, reduction of methane production increases rumen propionate since methane production is inversely proportional with propionate production. Leucaena leucocephala give many benefit e.g. for ruminant that will have a good impact in the term of ruminant nutrition and global environmental contribution through reducing methanogens in the rumen.
\end{abstract}

Keywords: amplification, feeding, Leucaena leucocephala, methane

\section{Introduction}

The livestock sector contributes to the improvement of the quality of human life. Livestock adds value to a number of resources that could not otherwise be utilized by the farming family, like the biomass (weeds, maize straw, cultivated forages, common grazing areas, surplus grain, etc.), by transforming it into valuable products (meat, milk, eggs), services (draught and pack power), or investment and biogas (Suwignyo et al., 2006; Crawford et al., 1978; Arriaga-Jordan et al., 2005), as well as contributes to the household economy (Hodges, 2003). Kamra (2005) stated that in tropical countries, the ruminants are fed with agricultural by-products like cereal straws, stovers, sugarcane bagasse, and fruit pulps. Most agricultural by-products are of poor quality but are high in fiber content (cellulose and hemicelluloses, lignin). Agus et al. (2005) stated that rice straw is a common agricultural by-product that is usually given by the farmer. This is not only practiced in the rural areas but also in commercial scale because it is abundant and cheap. A poor quality diet leads to inefficient digestion, which leads to increased methane production and lowered animal productivity (Gibs \& Hogan, 1990; Eckard, 1999; Nicholson et al., 2001). Methane $\left(\mathrm{CH}_{4}\right)$ is considered as one of the largest sources of greenhouse gas from feedlot and dairy farm, aside from nitrous oxide $\left(\mathrm{N}_{2} \mathrm{O}\right)$ and carbon dioxide $\left(\mathrm{CO}_{2}\right)$. Methane production is triggered by poor quality feeds (O'mara, 2004; Nicholson et al., 2001). The existence of methane in the rumen as product of fermentation maybe consider as inefficient because $\mathrm{CH}_{4}$ emissions represent an economic loss to the farmer where feed is converted to $\mathrm{CH}_{4}$ rather than to useful product.

Discussions about productivity in livestock, especially in ruminants focus on microorganism in the rumen. A ruminant has a compound stomach where the microorganism (bacteria, fungi and protozoa) has the ability to digest the fibrous material and poor quality feed that contains cellulose and hemicelluloses (Dehority, 1998; Kamra, 2005). Methanogens are present in the rumen in large numbers which vary from $10^{7}$ to $10^{9}$ cells $/ \mathrm{ml}$ of rumen liquor depending upon the type of diet given to the animals, especially the fiber content in the ration (Kamra, 2005). There are a number of strategies that can be used to improve performance of rumen microbial and its productivity. Thus, providing ruminants with the best combination of pasture and concentrate feeding, improved feed and forage management and other practices to increase the digestibility and reduce residence 
digestion time in the rumen that will effectively reduce methane emissions from the herd (O'mara, 2004; Eckard, 1999; Zhaoli, 2003; Anonymous, 2005).

Legume is one of good quality forages that can be supplemented in the diet. Leucaena leucocephala leucocephala is an example of common legume that is cheap and easy to find in the field. Leucaena not only can be a source of protein for the ruminant but also source of tannins (Atega et al., 2003; Orden et al., 2002; Sevilla et al., 2003). It could affect the performance of microorganisms in the rumen as a system and ultimately can affect performance of the ruminant itself. Further research is needed to observe the diets strategy with legume on rumen methanogenic bacteria of cattle and buffalo.

\section{Materials and Method}

The experiment was conducted at the Beef Cattle Farm, Animal and Dairy Sciences Cluster, College of Agriculture, University of the Philippines Los Baños, College, Laguna. The study was conducted at the Animal and Dairy Sciences Cluster from October, 2008 to August, 2009. Three each of rumen fistulated native cattle and buffalo were used in this study. The animals were placed in individual digestion stalls and maintained in good health condition prior to and throughout the duration of the study.

Three diet formulations were tested: (I) $60 \%$ Napier $+40 \%$ concentrate, (II) $54 \%$ Napier $+40 \%$ concentrate + $6 \%$ Leucaena leucocephala and (III) $48 \%$ Napier $+40 \%$ concentrate $+12 \%$ Leucaena leucocephala. The tannin content in the diet was around $0 \%, 0.3 \%$ and $0.6 \%$ of the diet. The chemical composition of the ingredient is shown in Table 1.

Table 1. Chemical composition of ingredient offered to animals*

\begin{tabular}{lllll}
\hline Feed Stuff & DM (\%) & CP $(\%)$ & NDF (\%) & Tannin (\%) \\
\hline Commercial concentrate & 88.01 & 13.54 & 21.03 & - \\
Napier grass & 24.80 & 8.70 & 70.72 & - \\
Leucaena leucocephala & 23.60 & 23.90 & 36.58 & $5.11 * *$ \\
\hline
\end{tabular}

Note. *: Analysis result at Nutrition and DTRI Laboratory, ADSC, UPLB; **: Hess et al. (2007).

Each experimental period tested for 17 days consisting of 10 days for dietary adjustment and 7 days for data collection. During the first 5 days of the 10-day of the preliminary period until the desired amount has been reached, Leucaena leucocephala was gradually given to the animals. Animals were provided with clean water at all times. DNA was extracted from rumen liquid using the procedure of Sharma et al. (2003) for isolating genomic DNA from rumen digesta. Modifications of the original protocol included incubation at $65{ }^{\circ} \mathrm{C}$ then freezing at $-80{ }^{\circ} \mathrm{C}$ for $30 \mathrm{~min}$ each, repeated 5 times.

Three universal primers were used to detect the different species in the different feeding trials. The PCR reaction mixture contained $2.0 \mu \mathrm{l}$ of $10 \mathrm{x}$; $0.6 \mathrm{Taq}$ polymerase buffer $(50 \mathrm{mM} \mathrm{MgCl}) ; 0.5 \mu \mathrm{l}$ of forward primer $(20 \mu \mathrm{M})$; $0.5 \mu \mathrm{l}$ of reverse primer $(10 \mu \mathrm{M}) ; 0.16 \mu \mathrm{l}$ of $\mathrm{dNTP}(25 \mathrm{mM}), 0.04 \mu \mathrm{l}$ of Taq polymerase $(0.2 \mathrm{u} / \mu \mathrm{l}) ; 1 \mu \mathrm{l}$ of DNA $\left(6.84 \mathrm{ng} / \mu \mathrm{l}\right.$ ); add $\mathrm{ddH}_{2} \mathrm{O}$ (sterile) to total volume $20 \mu \mathrm{l}$. The reaction was carried out in a PCR G-Storm, as follows: $30 \mathrm{~s}$ at $94{ }^{\circ} \mathrm{C}$ for denaturing, $30 \mathrm{~s}$ at $60{ }^{\circ} \mathrm{C}$ for annealing and $30 \mathrm{~s}$ at $72{ }^{\circ} \mathrm{C}$ for extension $(30$ cycles), except for 9 min denaturation in the first cycle and 10 min extension in the last cycle. Number of cycle in the PCR set was reduced into 20 cycles for optimization purpose. Products of PCR were separated on agarose gel, stained with ethidium bromide, and photographed. Adobe Photoshop program was used to edit the gel image. The same sampling procedure, data collection, laboratory analysis was done for DNA extraction and amplification.

\section{Results}

The agarose gel showing PCR amplification products at 30 cycles of methanogenic bacteria of buffalo and cattle fed Napier supplemented with Leucaena leucocephala are shown in Figure 1. 


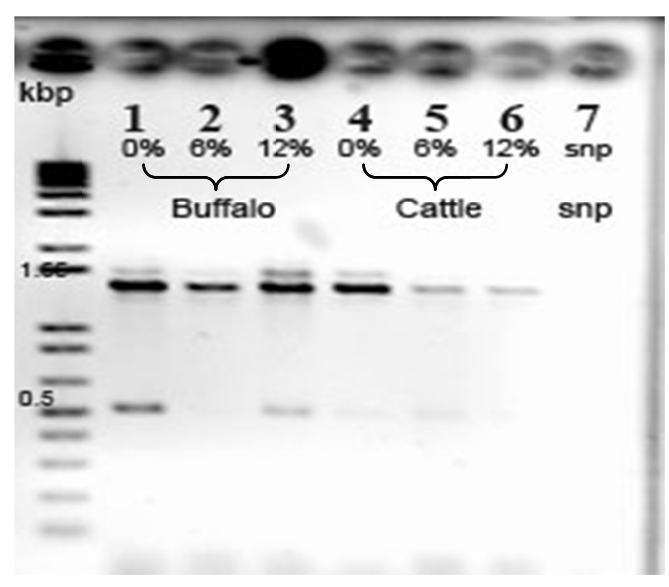

Figure 1. PCR amplification of universal primers Methanogens (PCR 30 cycles) at $1.4 \mathrm{kbp}$, affected by Leucaena leucocephala in the diet

Bands exist in the size at 500 and $1.4 \mathrm{kbp}$, and this can be observed in the 30 cycles PCR. The bands standing in $1.4 \mathrm{kbp}$ was for methanogens. The intensity of bands $(1.4 \mathrm{kbp})$ in agarose gel of sample taken from buffalo and cattle was decreased, eventhough in cattle was clearer than buffalo. It may indicate that Leucaena leucocephala inhibits methanogenic bacteria in the rumen of cattle, but has no effect in the buffalo. The possible methanogenic bacteria in $1.4 \mathrm{kbp}$ are Methanobacterium formicicum (1.45 kbp), Methanosarcinia barkery (1.45 kbp), Methanomicrobium mobile (1.44 kbp), and Thermoplasma acidophilum (1.44 kbp).

The observed result about methanogens was inline with the finding result of PCR amplification on potential population of cellulolityc bacteria changed with different diets. The agarose gel showing PCR amplification products at 20 cycles of cellulolityc bacteria of buffalo and cattle fed Napier supplemented with Leucaena leucocephala are shown in Figure 2.

A

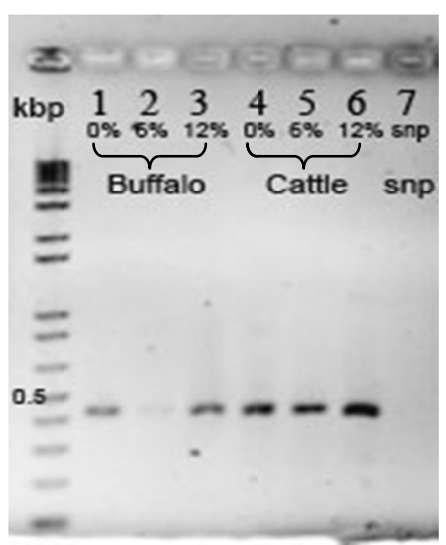

B

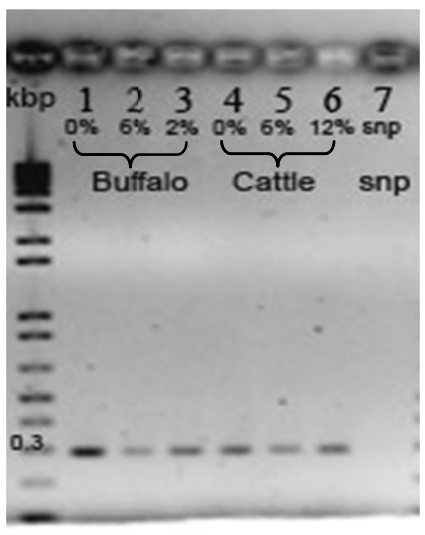

$\mathrm{C}$

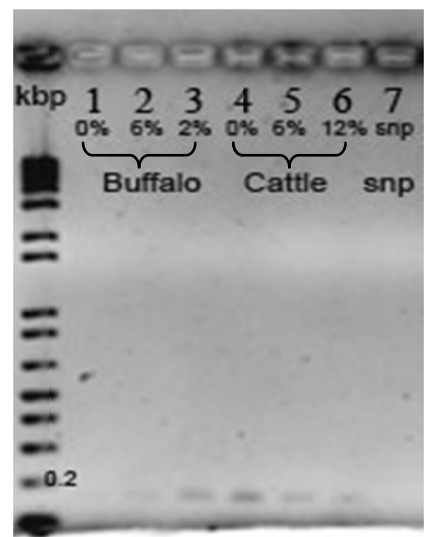

Figure 2. PCR amplification (20 cycles) of Fibrobacter succinogenes (A) at $445 \mathrm{bp}$, Ruminococcus flavefaciens (B) at $295 \mathrm{bp}$, and Ruminococcus albus (C) at $176 \mathrm{bp}$

There were no differences observed in the intensity of bands due to different levels of Leucaena leucocephala in the 30 cycles PCR product in F.succinogenes, R.albus and R. flavefaciens both of buffalo and cattle. On the optimization of PCR with shorter cycle (20 cycles), it was shown that levels of Leucaena leucocephala in the diet affected the intensity of the band. It was vice versa with $R$. flavefaciens from buffalo and cattle, decreased with $6 \%$ and $12 \%$. The bands intensity of $F$. succinogenes and $R$. flavefaciens of buffalo and cattle were an indication that Leucaena leucocephala in the diet enhanced the population of $F$. succinogenes but decreased $R$. flavefaciens. 


\section{Discussion}

Most methanogenic bacteria in cattle were affected by Leucaena leucocephala (wich was also source of tannin), thus methane production in the cattle has the possibility of being reduced with dietary treatment. Kamra (2005) stated that methanogens play a vital role in the rumen of scavenging molecular hydrogen generated during rumen fermentation, resulting in a significant loss of gross energy consumed by the animals. Similar opinion was stated by Eckard (1999), Zhaoli (2003), McGinn et al. (2004), and CCTP (2005).

Enhancing the the population of $F$. succinogenes can be intrepreted that propionate production will increase while methane will decrease. It can be explained by the finding of previous researchs. The only F. succinogenes among three major cellulolityc bacteria that can produce succinate (will turn to be propionate) in the rumen fermentation processes (Findlay, 1998; Russell \& Rychlik, 2001). Succinate is an intermediate compound for the production of propionate (Lana et al., 1998). Reducing methane and increasing propionate migh be affect on productivity in order to propionate has greater effect to production compare with acetate, since propionate will be used by animal in the gluconeogenesis (Allen, 2003). Three major cellulolityc bacteria that considered to be representative cellulolytic bacteria of the rumen are Fibrobacter succinogenes (19.2\%), Ruminococcus albus, and Ruminococcus flavefaciens (59.8\%) (Kamra, 2005; Koike et al., 2003).

Methane production is inversely proportional with propionate production, so that the reduction of methane production will be followed by increasing rumen propionate (Fellner, 2005; Kamra, 2005; Zhaoli, 2003; Eckard, 1999; van Nevel et al., 1971). The increasing rumen propionate is more beneficial in increasing the capture of fermentation energy since it reduces carbon that would be lost in the form of methane. In turn, the reduction in rumen methane production will increase the efficiency of nutrient utilization in the rumen; therefore improving productivity. Eckard (1999) stated that methane gas is a significant loss of energy from the production system that can and should be redirected back into production. In general, 2\% to 12\% (Zhaoli, 2003); $6.5 \%$ (McGinn et al., 2004); 7\% (Visser, 2005) of the total energy consumed assimilated by ruminants is lost in the form of methane. Reducing methane production invariably increases rumen propionate (Fellner, 2005).

Supplementation of Leucaena leucocephala in the diet not only increased the quality of diet with increasing crude protein level, but may also inhibit methanogens. Decreasing methanogens population in the rumen will have two beneficial impacts, on the part of the animal and that of the environment. In animals, reduction of methanogens will decrease the amount of methane production. Luc et al. (2009) stated that higher level of dietary crude protein lead to increase rumen ammonia concentration. Increasing rumen ammonia concentration through supplementation of protein in the diet like Leucaena leucocephala could result in increased VFA production and population of cellulolytic bacteria. Topps (1995) stated that legume increases the total concentration of VFA without affecting its relative proportions of the rumen $\mathrm{pH}$. Feeding Leucaena leucocephala may also stimulate the growth of cellulolytic microorganisms that produce propionate like $F$. succinogenes.

The effect of Leucaena leucocephala, particularly on inhibiting methanogens, would not only result in increasing nutrient utilization by the animal but also would have subsequent impact on preserving the environment. Hegarty (1999) stated that methanogens living on and within rumen ciliate protozoa may be responsible for up to $37 \%$ of the rumen methane emissions. Methane is considered as one of the largest sources of greenhouse gas (GHG) aside from nitrous oxide $\left(\mathrm{N}_{2} \mathrm{O}\right)$ and carbon dioxide $\left(\mathrm{CO}_{2}\right)$. Methane is 21 times more potent than $\mathrm{CO}_{2}$ as $\mathrm{GHG}, 1$ $\mathrm{kg}$ of methane is equivalent to $21 \mathrm{~kg}$ of $\mathrm{CO}_{2}$ (O'mara, 2004). Methane emitted from the livestock sector accounts for 38\% of all agricultural GHG emissions in Canada (McGinn et al., 2004) and 17.7\% in Australia (Eckard, 1999).

Around 15\%-20\% of results of climate warming are due to methane (Gibs \& Hogan, 1990; Zhaoli, 2003). Thus, reducing methane emission from livestock would significantly favor the environment. In this study, supplementation Leucaena leucocephala can be implemented as feeding management for buffalo and cattle. The amount of methane emitted is dependent on the animal's digestive system and the amount and type of feed consumed (Eckard, 1999; McGinn et al., 2004; CCTP, 2005). Furthermore, a number of strategies can be used, including increased digestibility of forages and feeds, modification of bacteria in the rumen, improved feed and forage management and treatment practices to increase the digestibility, treatment of the feeds/forages to increase digestibility, and appropriate use of concentrated supplements.

Increasing livestock productivity through better feeding and management will promote increased food supply for the household. About one-third of the dietary protein and one-sixth of the food energy consumed by humans come from systems involving livestock. Increasing animal product consumption could improve the health of 
pregnant and lactating women, growth and neurobehavioral development of young children, and cognitive development in children (Nicholson et al., 2001).

Leucaena leucocephala in the diet of ruminants able to inhibit methanogens (reduce methane) and enhance Fibrobacter succinogenes which is potential to produce propionic acid. Methane emissions can be target of livestock-specific policies, given the potential for increasing productivity through reduction of dietary energy lost in methane. Providing more source of $L$. leucocephala through planting will give more benefit to community and environment. Planting of L. leucocephala trees as fence or strip cropping will become good investment for farmer who raises ruminants. Leucaena leucocephala give many benefit e.g. increase soil quality, source of leaf protein for ruminant and source of tannin that will have a good impact in the term of ruminant nutrition and global environmental contribution through reducing methanogens in the rumen.

\section{References}

Agus, A., Suwignyo, B., \& Utomo, R. (2005). Utilization of Complete Feed Based on Fermented Rice Straw for Australian Commercial Cross Steer on The Nutrient Intake, Feed Conversion Ratio and Average Daily Gain. Buletin Peternakan, 29(1), 1-9. http://dx.doi.org/10.21059/buletinpeternak.v29i1.1147

Allen, M. (2003). Forages, Fiber and the Rumen. The AABP Proceedings (Vol. 36). American Association of Bovine Practitioners.

Anonymous. (2005). Advanced Agricultural Systems for Enteric Emissions Reduction. U.S. Climate Change Technology Program (pp. 4.2-7).

Arriaga-Jordan, C. M., Pedraza-Fuentes, A. M., Nava-Bernal, E. G., Chavez-Mejia, M. C., \& Castelan-Ortega, O. A. (2005). Livestock Agrobiodiversity of Mazahua Smallholder Campesino Systems in The Highland of Central Mexico. Human Ecology, 33(6), 821-845. http://dx.doi.org/10.1007/s10745-005-8212-9

Atega, T. A., Alinea, C. B., Rayos, A. A., \& Robles, A. Y. (2003). Leaf Meals of Gliricidiasepium and Samaneasaman as Protein Supplements for Goats. Philippines Journal of Veterinary and Animal Sciences, 29(1), 93-99.

CCTP. (2005). Advanced Agricultural Systems for Enteric Emissions Reduction. U.S. Climate Change Technology Program - Technology Options for the Near and Long Term (pp. 4.2-7).

Crawford, D. F., Anthony, W. B., \& Harris, R. R. (1978). Evaluation of Concentrated Hemicelluloses Extract as Cattle Feed. Journal of Animal Science, 46(1), 32-40.

Dehority, B. A. (1998). Microbial Interaction in the Rumen. Rev. Fac. Agron., 15, 69-86. Retrieved from http://www.revfacagronluz.org.ve/v15_1/v151z009.html

Eckard, J. R. (1999). Best Management Practices for Reducing Greenhouse Gas Emissions from Dairy Farms. ILFR, The University of Melbourne. Retrieved March 30, 2008, from http://www.greenhouse.unimelb. edu.au/gia.htm

Fellner, V. (2005). Rumen Microbes and Nutrient Management. California ARPAS Conference, October, 2002, Coalinga, CA. North Carolina State University Animal Science Departmental Report 2004-2005.

Findlay, A. L. R. (1998). Microbiology of the Rumen and Small and Large Intestines. Physiological Laboratory, University of Cambridge, Australia.

O'mara, F. (2004). Greenhouse Gas Producing From Dairying: Reducing Methane Production. Advances in Dairy Technology, 16, 295.

Gibs, R. J., \& Hogan, K. (1990). Methane. EPA Journal Mart, 16(2).

Hegarty, R. S. (1999). Reducing rumen methane emissions through elimination of rumen protozoa. Australian Journal of Agricultural Research, 50(8), 1321-1328. http://dx.doi.org/10.1071/AR99008

Hodges, J. (2003). Livestock, Ethics, and Quality of Life. J. Anim. Sci., 81(11), 2887-2894.

Kamra, D. N. (2005). Rumen Microorganism Ecosystem.Microbiology Section, Centre of Advanced Studies in Animal Nutrition. Current Science (Vol. 89, No. 1). Indian Veterinary Research Institute, Izatnagar, India.

Koike, S., Pan, J., Kobayashi, Y., \& Tanaka, K. (2003). Kinetics of in Sacco Fiber-Attachment of Representative Ruminal Cellulolytic Bacteria Monitored by Competitive PCR. Journal of Dairy Science, 86(4), 1429-1435. http://dx.doi.org/10.3168/jds.S0022-0302(03)73726-6

Lana, R. P., Russell, J. B., \& Amburgh, M. E. Van. (1998). The role of $\mathrm{pH}$ in regulating ruminal methane and ammonia production. Journal of Animal Science, 76(8), 2190-2196. 
McGinn, S. M., Beauchemin, K. A., Coates, T., \& Colombatto, D. (2004). Methane Emissions From Beef Cattle: Effects of Monensin, Sunflower Oil, Enzymes, Yeast, and Fumaric Acid. Journal of Animal Science, 2004(82), 3346-3356.

Nicholson, C. F., Blake, R. W., Reid, R. S., \& Schelhas, J. (2001). Environmental Impacts of Livestock in the Developing World. Environment: Science and Policy for Sustainable Development, 43(2), 7-17. http://dx.doi.org/10.1080/00139150109605120

Orden, E. A., Cruz, E. M., Ichinohe, T., \& Fujihara, T. (2002). Effects of Leucaena Leucocephala and Gliricidia Sepium Supplementation on Outflow Rate, Microorganism Protein Yield and Growth of Sheep Fed With Ammoniated Rice Straw. Philippine Journal of Veterinary and Animal Science, 28(1), 63-71.

Russelll, J. B., \& Rychlik, J. L. (2001). Factors That Alter Rumen Microorganism ecology. Retrieved March 30, 2008, from http://www.eduplace.com/kids/scienceglossary

Sevilla, C. C., Bejo, M., \& Billena, M. S. (2003). The Effects of Maceration of Leucaena (Leucaena leucocephala) on the Rumen degradation of its Protein in Cattle. Philippine Journal of Veterinary and Animal Science, 29(1), 37-43.

Sharma, R., John, S. J., Damgaard, D. M., \& Mcallister, T. A. (2003). Extraction of PCR-Quality Plant and Microbial DNA from Total Rumen Contents. Short Technical Reports. Biotechniques, 34(1), 92-97.

Suwignyo, B., Padmowijoto, S., \& Ali, A. (2006). Cattle Agroforestry Production System in Sandy Land to Alleviate Poor Farmer. Proceeding of International Seminar and Workshop. The Role of Agro forestry Education in The Revitalization Action of Agriculture, Fishery and Forestry Program and Second General Meeting of INAFE: Policy Recommendation and Campaign. UGM-SEANAFE. Yogyakarta, Indonesia, February 7, 2006.

Topps, J. H. (1995). Forage legumes as protein supplements to poor quality diets in the semi-arid tropics. Rumen Ecology Research Planning. Proceedings of a Workshop the International Livestock Research Institute. March 13-18, 1995, Addis Ababa, Ethiopia.

Van Nevel, C. J., Demeyer, D. I., \& Henderickx, H. K. (1971). Effect of Fatty Acid Derivatives on Rumen Methane and Propionate In Vitro. Applied Microbiology, 21(2), 365-366.

Zhaoli, L. Y. (2003). Animal Husbandry Production and Global Climate Change. Faculty of Animal Science and Technology, Jilin Agricultural University, Changchun, Jilin, China. Retrieved March 30, 2008, from http://www.coalinfo.net.cn/coalbed/meeting/2203/papers/agriculture/AG091.pdf

\section{Copyrights}

Copyright for this article is retained by the author(s), with first publication rights granted to the journal.

This is an open-access article distributed under the terms and conditions of the Creative Commons Attribution license (http://creativecommons.org/licenses/by/4.0/). 